\title{
CTRC wt Allele
}

National Cancer Institute

\section{Source}

National Cancer Institute. CTRC wt Allele. NCI Thesaurus. Code C118558.

Human CTRC wild-type allele is located in the vicinity of 1 p36.21 and is approximately 11 $\mathrm{kb}$ in length. This allele, which encodes chymotrypsin- $\mathrm{C}$ protein, is involved in the proteolytic activation of other serine proteinases. Mutation of the gene is associated with hereditary pancreatitis. 